\title{
Mass of agricultural tractors available in the brazilian market
}

\author{
Massa dos tratores agrícolas comercializados no mercado brasileiro
}

\section{Javier Solis Estrada ${ }^{I^{*}}$ José Fernando Schlosser $^{I I}$ Marcelo Silveira de Farias $^{\mathrm{I}}$ Alfran Tellechea Martini ${ }^{I}$ Gustavo Oliveira dos Santos ${ }^{I}$}

\section{ABSTRACT}

Currently, manufacturers of agricultural tractors offer to farmers a diversity of brands, models, and settings for the most diverse agricultural operations. In this sense, the relation mass/power of tractor influences directly in the performance of these operations. The objective of this research was to study the agricultural wheel tractors marketed in Brazil in relation to their mass, in order to obtain current data to help their selection and proper use. The research involved 145 agricultural tractors models of eight different brands, including $2 W D, M F W D$ and $4 W D$ versions. The variables mass without ballast, relation mass/power for the different brands, type of traction and tractor power were analyzed separately. Tractor power was classified in: Class I $(<50 \mathrm{~kW})$, Class II $(50$ to $150 \mathrm{~kW})$ and Class III $(>150 \mathrm{~kW})$, according to the rated engine power declared by the manufacturer. Statistical analyses used were the t-Student and Tukey tests. The most number of tractors belongs to Class II and are considered versatile due to their mass/power relation, and can be used in the most diverse agricultural operations. From these analyses it was detected the mass/power relation decreases when the rated engine power increases.

Key words: sizing machines, agricultural mechanization, mass/ power ratio.

\section{RESUMO}

Atualmente, os fabricantes de tratores agrícolas disponibilizam aos agricultores uma diversidade de marcas, modelos e configurações para as mais diversas operações agricolas. Nesse sentido, a relação massa/potência do trator influencia de forma direta no desempenho dessas operações. Objetivou-se estudar os tratores agrícolas de rodas comercializados no mercado brasileiro, no que se refere a sua massa, visando obter dados atuais que auxiliem sua seleção e uso adequado. A pesquisa envolveu
145 modelos de tratores agricolas de oito marcas diferentes, contemplando as versões 4x2, TDA e 4x4. Foram analisadas separadamente as variáveis massa sem lastro e relação massal potência para as diferentes marcas, tipo de tração e potência do trator, sendo esta última classificada em: Classe I (menores que $50 \mathrm{~kW}$ ), Classe II (entre 50 e $150 \mathrm{~kW}$ ) e Classe III (maiores que $150 \mathrm{~kW}$ ), de acordo com a potência nominal do motor, declarada pelo fabricante. As análises estatísticas foram realizadas por meio dos testes $t$ de Student e Tukey. O maior número de tratores pertence à Classe II, sendo considerados versáteis, devido à sua relação massa/potência, podendo ser usados nas mais diversas operações agrícolas. Há uma tendência de os tratores agrícolas comercializados no mercado brasileiro diminuírem sua relação massa/potência, conforme aumenta a potência nominal do motor.

Palavras-chave: dimensionamento de máquinas, mecanização agrícola, relação massa/potência.

\section{INTRODUCTION}

The tractor stands out in the world's agricultural development, due to its versatility, serving as a source of power and traction to numerous implements and agricultural machinery used in mechanized operations on a farm. As a fundamental tool in raising production standards, the tractor now has widespread its use, generating an acceleration in its production (MÁRQUEZ, 1990). According to BILSKI (2013), there are about 29 million tractors in the world.

In Brazil, according to the National Association of Vehicle Manufacturers (ANFAVEA,

\footnotetext{
IPrograma de Pós-graduação em Engenharia Agrícola (PPGEA), Universidade Federal de Santa Maria (UFSM), 97105-900, Santa Maria, RS, Brasil. E-mail: j.solis.estrada@gmail.com. .Corresponding author.

IDepartamento de Engenharia Rural (DER), Centro de Ciências Rurais (CCR), Universidade Federal de Santa Maria (UFSM), Santa Maria, RS, Brasil. 
2014), the internal market for wheel tractors, in 2013, absorbed 65,089 new units, $16.61 \%$ more tractors than on the previous year. In addition to the engine power and the power transmission system efficiency, the tractor is characterized by its dimensions and by its mass. Important dimensions of a tractor for its work are the wheelbase, track gauge, the center of gravity and the height of the implement coupling point (LINARES et al., 2006).

As its mass, it is important to know its original factory setting, accessories, willingness to increase it (metal weights) and possibility of changing the distribution of the original mass (ballast), between tractor axles. According to MÁRQUEZ (1990), tractor mass influences on its performance in the field. Moreover, it is an important parameter in defining suitability to perform certain tasks (BIONDI et al., 1996; LINARES et al., 2006).

From the knowledge of the power supplied by the tractor engine and its mass the mass/power ratio can be calculated. Over the years, tractors are becoming lighter, as well as the mass/ power ratio has been reduced, and this reduction is greater for higher power tractors (LAPERUTA FILHO et al., 1989; MÁRQUEZ, 1990; RENIUS, 1994; SCHLOSSER et al., 2005).

According to MONTEIRO et al. (2009), adding mass to the tractor obeying the mass/power ratio criteria brings improvements in terms of operating capacity. For different models of tractors, average yield on the drawbar may vary depending on the relationship between mass and engine power (MONTEIRO et al., 2011).

The objective of this research was to study wheel agricultural tractors marketed in Brazil, in relation to its mass in order to obtain current data to assist their selection and proper use.

\section{MATERIALS AND METHODS}

The research involved 145 models of agricultural tractors of the brands Agrale, Case IH, John Deere, Landini, Massey Ferguson, New Holland, Valtra and Yanmar, contemplating versions with, simple traction $(4 \times 2)$, mechanic front wheel drive (MFWD) and all-wheel drive $(4 \times 4)$. Some analyzed tractors brands do not have all the settings for the type of traction.

The tractors were classified into three classes, according to the rated engine power provided by the manufacturer: Class I (less than $50 \mathrm{~kW}$ ), Class II (from 50 to $150 \mathrm{~kW}$ ) and Class III (higher than $150 \mathrm{~kW})$. To differentiate models evaluated, tractor mass variables (unballasted) were considered $(\mathrm{kg})$ and mass/power ratio $\left(\mathrm{kg} \mathrm{kW}^{-1}\right)$. Data were acquired through technical information provided by the manufacturers. For standardization of terms, when it was called mass, it was refered to the tractor unballasted mass.

For determining significant differences at the level of 5\% probability of error, among the variables analyzed (brands, traction type and power class), t-Student and Tukey tests were used, with the help of Sisvar software, version 5.3 (FERREIRA, 2011).

\section{RESULTS AND DISCUSSION}

From the 145 models of evaluated tractors, 16 are $2 \mathrm{WD}, 118$ are type MFWD and 11 are allwheel drive (4WD). It was found that depending on the type of traction, there were differences among the evaluated brands, as its mass for 2WD and MFWD tractors, power for tractors with MFWD and mass/ power ratio for MFWD and 4WD tractors (Table 1). These results differ from those obtained by SCHLOSSER et al. (2005), when analyzing the mass/ power ratio of agricultural tractors sold in Brazil with 2WD and MFWD, reported no difference.

By analyzing the $4 \times 2$ tractors, it is observed that for the mass variable, tractors of Valtra brand are heavier than tractors from Massey Ferguson, and, they do not differ from Agrale, New Holland and Case IH tractors. But for the variable rated power and mass/power ratio, there was no significant difference in brands evaluated.

As for the models with MFWD, it is observed that the greater mass of the tractors are John Deere and Valtra brands, and the lighter are the ones from Yanmar. For Agrale, Landini, Massey Ferguson, New Holland and Case IH brands there was no significant difference concerning their masses. It is observed that for the mass/power ratio the same tendency happens, where John Deere and Valtra tractors have higher values, which are not statistically different from the other brands, except for Yanmar tractors.

For 4WD models, to analyze the variables mass and power, there was no statistical difference between brands evaluated. As for the mass/power ratio the highest and lowest values in John Deere and New Holland tractors, respectively, were observed; which differ from each other, the latter did not differ statistically from the Case IH values.

By analyzing the tables 1 and 2, it is observed that the average weight variable values vary depending on brand and type of traction, which agrees with the data obtained by SCHLOSSER et 
Table 1 - Comparison between the average of mass and mass/power ratio, according to the type of traction, of agricultural tractors available in the Brazilian market.

\begin{tabular}{|c|c|c|c|c|c|c|c|}
\hline & $\mathrm{Q}$ (unity) & \multicolumn{2}{|c|}{ Mass (kg) } & \multicolumn{2}{|c|}{ Power $(\mathrm{kW})$} & \multicolumn{2}{|c|}{ Mass/power ratio $\left(\mathrm{kg} \mathrm{kW}^{-1}\right)$} \\
\hline Average & 16 & \multicolumn{2}{|c|}{2895.44} & \multicolumn{2}{|c|}{55.22} & \multicolumn{2}{|c|}{53.39} \\
\hline Maximum & 1 & \multicolumn{2}{|c|}{4180.00} & \multicolumn{2}{|c|}{77.20} & \multicolumn{2}{|c|}{71.27} \\
\hline Minimum & 1 & \multicolumn{2}{|c|}{2227.00} & \multicolumn{2}{|c|}{36.76} & \multicolumn{2}{|c|}{35.07} \\
\hline Agrale & 2 & 3140.00 & $a b$ & 58.83 & $\mathrm{a}$ & 53.49 & $\mathrm{a}$ \\
\hline Massey Ferguson & 5 & 2471.40 & $\mathrm{~b}$ & 48.16 & a & 53.88 & $\mathrm{a}$ \\
\hline New Holland & 2 & 2835.00 & $a b$ & 57.00 & $\mathrm{a}$ & 49.74 & $\mathrm{a}$ \\
\hline Case IH & 2 & 2745.00 & $a b$ & 47.79 & $\mathrm{a}$ & 57.44 & $\mathrm{a}$ \\
\hline Valtra & 5 & 3306.00 & A & 63.08 & $\mathrm{a}$ & 52.71 & $\mathrm{a}$ \\
\hline Average & 118 & \multicolumn{2}{|c|}{4894.86} & \multicolumn{2}{|c|}{93.54} & \multicolumn{2}{|c|}{52.52} \\
\hline Maximum & 1 & \multicolumn{2}{|c|}{12000.00} & \multicolumn{2}{|c|}{276.00} & \multicolumn{2}{|c|}{74.80} \\
\hline Minimum & 1 & \multicolumn{2}{|c|}{1365.00} & \multicolumn{2}{|c|}{26.00} & \multicolumn{2}{|c|}{37.09} \\
\hline Agrale & 13 & 3481.54 & bc & 66.34 & $a b$ & 52.06 & $a b$ \\
\hline Landini & 11 & 3549.09 & bc & 64.81 & $\mathrm{ab}$ & 52.38 & $a b$ \\
\hline Yanmar & 10 & 1546.00 & $\mathrm{c}$ & 35.77 & $\mathrm{~b}$ & 43.91 & $\mathrm{~b}$ \\
\hline Massey Ferguson & 7 & 4854.29 & $a b c$ & 106.97 & $\mathrm{ab}$ & 52.84 & $\mathrm{ab}$ \\
\hline John Deere & 18 & 6726.94 & A & 123.16 & $\mathrm{a}$ & 53.84 & $\mathrm{a}$ \\
\hline New Holland & 25 & 5006.52 & $a b$ & 92.58 & $a b$ & 53.83 & $\mathrm{a}$ \\
\hline Case IH & 16 & 4786.88 & $\mathrm{abc}$ & 94.35 & $a b$ & 50.28 & $\mathrm{ab}$ \\
\hline Valtra & 18 & 6723.06 & A & 123.43 & $\mathrm{a}$ & 56.42 & $\mathrm{a}$ \\
\hline Average & 11 & 17264.18 & & 366.03 & & 47.48 & \\
\hline Maximum & 1 & 19979.00 & & 447.00 & & 57.17 & \\
\hline Minimum & 1 & 14131.00 & & 298.00 & & 42.64 & \\
\hline John Deere & 4 & 18160.75 & A & 356.75 & a & 51.37 & $\mathrm{a}$ \\
\hline New Holland & 5 & 16186.60 & A & 370.60 & a & 43.88 & $\mathrm{~b}$ \\
\hline Case IH & 2 & 18165.00 & $\mathrm{~A}$ & 373.16 & $\mathrm{a}$ & 48.68 & $a b$ \\
\hline
\end{tabular}

Averages followed by the same letter down do not differ significantly by Tukey test at $5 \%$ level.

al. (2005). As it can be seen, Yanmar brand has the smallest mass, 4.42 times less when compared to average of John Deere, Valtra, New Holland and Case IH tractors. Tractors Massey Ferguson present intermediate mass compared to other brands, and do not differ from Agrale, Landini and Case IH (Table 2).

Tractors of the Yanmar, besides having a smaller mass, are those with the lowest ratio mass/power, differing from other brands. Aside from Case IH and Valtra tractors, there was no significant difference among the other brands evaluated (Table 2). In this sense, the differences may be related to the construction characteristics of the tractor, and the tractors from Case IH were considered lighter while the Valtra tractors were considered heavier in relation to the other.
Comparing the mass of the tractors available in the Brazilian market in accordance with the performance classes, it is observed that there was significant difference them (Table 3). It can be seen that Class III tractors reached an average mass of $13207 \mathrm{~kg}$, which is 2.89 times the average mass found for Class II tractors $(4575 \mathrm{~kg})$.

The mass/average power ratio decreases when tractors engine power increases, and there was no significant difference when comparing their values (Table 3). By observing the Class I tractors, one realizes that its mass/average power ratio is 1.38 and 5.97\% higher when compared with Classes II and III tractors, respectively. It can be said that the mass/ power ratio decreased primarily by constructive limits of weight in high-power tractors. Similar results were reported by SCHLOSSER et al. (2005), which state 
Table 2 - Comparison between the average mass and mass/power ratio according to the different brands of agricultural tractors available in the Brazilian market.

\begin{tabular}{|c|c|c|c|c|c|c|c|c|c|}
\hline \multirow{2}{*}{ Brands } & \multirow{2}{*}{ Average } & \multirow{2}{*}{ Agrale } & \multirow[b]{2}{*}{ Landini } & \multirow[b]{2}{*}{ Yanmar } & \multirow[b]{2}{*}{ Massey Ferguson } & \multirow[b]{2}{*}{ John Deere } & \multirow[b]{2}{*}{ New Holland } & \multirow[b]{2}{*}{ Case IH } & \multirow[b]{2}{*}{ Valtra } \\
\hline & & & & & & & & & \\
\hline 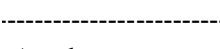 & & & & & Mass (kg)--- & & & $*$ & ---- \\
\hline Agrale & 3436.00 & - & ns & * & ns & * & $*$ & $*$ & ${ }^{*}$ \\
\hline Landini & 3549.09 & ns & - & * & ns & $*$ & $*$ & * & * \\
\hline Yanmar & 1546.00 & ${ }^{*}$ & ${ }^{*}$ & - & $*$ & $*$ & $*$ & ${ }^{*}$ & $*$ \\
\hline Massey Ferguson & 3861.42 & ns & ns & * & - & $*$ & $*$ & ns & $*$ \\
\hline John Deere & 8805.82 & * & $*$ & $*$ & $*$ & - & $\mathrm{ns}$ & $*$ & $*$ \\
\hline New Holland & 6617.69 & * & $*$ & * & $*$ & ns & - & ns & $\mathrm{ns}$ \\
\hline Case IH & 5920.50 & * & $*$ & * & ns & $*$ & $\mathrm{~ns}$ & - & $\mathrm{ns}$ \\
\hline Valtra & 5980.22 & * & $*$ & $*$ & $*$ & * & $\mathrm{ns}$ & $\mathrm{ns}$ & - \\
\hline Agrale & 65.34 & - & ns & $*$ & Power $\left(\begin{array}{c}\mathrm{kW}) \\
\mathrm{ns}\end{array}\right.$ & * & * & * & ----- \\
\hline Landini & 64.81 & ns & - & $*$ & ns & $*$ & $*$ & $*$ & $*$ \\
\hline Yanmar & 35.77 & $*$ & $*$ & - & $*$ & $*$ & $*$ & $*$ & $*$ \\
\hline Massey Ferguson & 82.47 & ns & ns & * & - & $*$ & ns & ns & ns \\
\hline John Deere & 165.63 & $*$ & $*$ & $*$ & $*$ & - & $\mathrm{ns}$ & ns & $*$ \\
\hline New Holland & 133.80 & $*$ & $*$ & $*$ & ns & ns & - & ns & ns \\
\hline Case IH & 122.23 & $*$ & $*$ & $*$ & ns & ns & $\mathrm{ns}$ & - & ns \\
\hline Valtra & 110.31 & * & $*$ & $*$ & ns & $*$ & $\mathrm{~ns}$ & ns & - \\
\hline 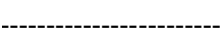 & --------- & - & - & --Mass/p & wer ratio $\left(\mathrm{kg} \mathrm{kW}^{-1}\right)$ & - & -- & & - \\
\hline Agrale & 52.25 & - & $\mathrm{ns}$ & $*$ & ns & ns & $\mathrm{ns}$ & ns & ns \\
\hline Landini & 52.38 & ns & - & $*$ & ns & ns & $\mathrm{ns}$ & ns & ns \\
\hline Yanmar & 43.91 & $*$ & $*$ & - & $*$ & $*$ & $*$ & $*$ & $*$ \\
\hline Massey Ferguson & 53.27 & ns & $\mathrm{ns}$ & $*$ & - & ns & $\mathrm{ns}$ & ns & ns \\
\hline John Deere & 53.39 & $\mathrm{~ns}$ & $\mathrm{~ns}$ & $*$ & ns & - & $\mathrm{ns}$ & ns & ns \\
\hline New Holland & 52.02 & $\mathrm{~ns}$ & ns & $*$ & ns & ns & - & ns & ns \\
\hline Case IH & 50.84 & ns & ns & $*$ & ns & ns & $\mathrm{ns}$ & - & $*$ \\
\hline Valtra & 55.61 & ns & ns & $*$ & ns & $\mathrm{ns}$ & ns & $*$ & - \\
\hline
\end{tabular}

${ }^{*}$ Significant contrast at $5 \%$ level by the t-Student test. ${ }^{\text {ns }}$ non-significant contrast at $5 \%$ level by t-Student test. - contrast between types of same power range.

that as the power of tractor engine increases, their weight/power ratio reduces.

It is observed that mass/power ratio of tractors currently marketed in Brazil varies in relation to the brand, power and type of traction. According to MÁRQUEZ (2012), the ratio weight/ power together with the constructive characteristics of the tires can be considered essential for achieving greater efficiency in the transformation of engine power in traction power.

According to RENIUS (1994), lower power tractors are generally used to perform light work. The mass/average power ratio reported in Classes I and II tractors eliminates the need for additional ballast in activities where high traction effort is not required. As for the 4WD tractors, a $47.48 \mathrm{~kg} \mathrm{~kW}^{-1}$ mass/average power ratio was reported, indicating that the use of additional ballast is needed in those tractors, since they are designed to work with heavy implements, requiring increased demand for traction. According to MÁRQUEZ (2012) for $4 \mathrm{WD}$ tractors the mass/power in operation ratio (with ballast) must approach $60 \mathrm{~kg} \mathrm{~kW}^{-1}$.

\section{CONCLUSION}

The availability of tractors with different mass configurations, power and type of traction offer greater choice to the farmer. The largest number of tractors belongs to Class II and is considered versatile for various agricultural operations, due to its mass/power ratio. There is a tendency of agricultural tractors having lower mass/power ratio, while engine power increases. 
Table 3 - Comparison between the average mass and mass/power ratio according to the different power ratings of agricultural tractors available in the Brazilian market.

\begin{tabular}{|c|c|c|c|c|}
\hline \multirow{2}{*}{ Classes of power } & \multirow{2}{*}{ Average } & \multicolumn{3}{|c|}{-------------Significance------------- } \\
\hline & & Class I & Class II & Class III \\
\hline \multicolumn{5}{|c|}{ 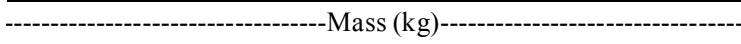 } \\
\hline Class I & 2213.14 & - & $*$ & ${ }^{*}$ \\
\hline Class II & 4575.40 & * & - & * \\
\hline Class III & 13207.70 & ${ }^{*}$ & * & - \\
\hline \multicolumn{5}{|c|}{-----'Mass/power ratio $\left(\mathrm{kg} \mathrm{kW}^{-1}\right)$} \\
\hline Class I & 53.44 & - & ns & ns \\
\hline Class II & 52.37 & ns & - & ns \\
\hline Class III & 50.25 & ns & ns & - \\
\hline
\end{tabular}

${ }^{*}$ Significant contrast at $5 \%$ level by the t-Student test. ${ }^{\mathrm{ns}}$ nonsignificant contrast at $5 \%$ level by t-Student test. - contrast between types of same power range.

\section{ACKNOWLEDGEMENTS}

The authors are grateful to the Coordenação de Aperfeiçoamento de Pessoal de Nível Superior (CAPES) for financial support. Also to the Conselho Nacional de Desenvolvimento Científico e Tecnológico $(\mathrm{CNPq})$ for research productivity scholarship of the second author.

\section{REFERENCES}

ANFAVEA (ASSOCIAÇÃO NACIONAL DOS FABRICANTES DE VEÍCULOS AUTOMOTORES). Anuário da indústria automobilística brasileira 2013. São Paulo, 2013. Available from: <http://www.anfavea.com.br/anuario.html>. Accessed: Jul. $12,2014$.

BILSKI, B. Exposure to audible and infrasonic noise by modern agricultural tractors operators. Applied Ergonomics, v.44, p. 210 214, 2013. Available from: <http://www.sciencedirect.com/ science/article/pii/S0003687012001093\#>. Accessed: Mar. 10, 2015. doi: 10.1016/j.apergo.2012.07.002.

BIONDI, P. et al. Technical trends of tractors and combines (19601989) based on Italian type-approval data. Journal of Agricultural Engineering Research, v.65, p.1-14, 1996. Available from: <http://
www.sciencedirect.com/science/article/pii/S0021863496900748>. Accessed: Mar. 19, 2015. doi: 10.1006/jaer.1996.0074

FERREIRA, D.F. Sisvar: a computer statistical analysis system. Ciência e Agrotecnologia, v.35, n.6, p.1039-1042, 2011. Available from: <http://www.scielo.br/scielo.php?pid=S141370542011000600001\&script $=$ sci_arttext $>$. Accessed: Mar. 19, 2015. doi: 10.1590/S1413-70542011000600001.

LAPERUTA FILHO, J. et al. Evolução do peso dos tratores agrícolas ensaiados no Brasil. In: CONGRESSO BRASILEIRO DE ENGENHARIA AGRÍCOLA, 18., 1989, Recife, PE. Anais... Recife: Universidade Federal Rural de Pernambuco, 1989. p.13.

LINARES, P. et al. Teoría de la tracción de tractores agrícolas. Madrid: ETSIA, 2006. 215p.

MÁRQUEZ, L.Solo Tractor’90. Madrid: Laboreo, 1990. 231p.

MÁRQUEZ, L. Tractores agrícolas: tecnología y utilización. Madrid: B\&H Grupo Editorial, 2012. 844p.

MONTEIRO, L.A. et al. Desempenho de um trator agrícola em função do tipo construtivo do pneu e da lastragem líquida em três velocidades de deslocamento na pista com superfície firme. Energia na Agricultura, v.24, n.1, p.68-84, 2009. Available from: $<$ http://revistas.fca.unesp.br/html/CD_REVISTA_ENERGIA vol24n1/vol24n12009/Leonardo\% 20 De\%20A1meida\% $2 \overline{0}$ Monteiro\%20final.pdf>. Accessed: Apr. 15, 2015.

MONTEIRO, L.A. et al. Desempenho de um trator agrícola equipado com pneus radiais e diagonais com três níveis de lastros líquidos. Engenharia Agrícola, v.31, n.3, p.551-560, 2011. Available from: <http://www.scielo.br/scielo.php?script=sci_artt ext\&pid=S0100-69162011000300015>. Accessed: Apr. 06, 2015. doi: 10.1590/S0100-69162011000300015.

RENIUS, K. Th. Trends in tractor design with particular reference to Europe. Journal of Agricultural Engineering Research, v.57, p.3-22, 1994. Available from: <http://www.sciencedirect.com/ science/article/pii/S002186348471002X>. Accessed: Apr. 06, 2015. doi: 10.1006/jaer.1994.1002.

SCHLOSSER, J.F. et al. Análise comparativa do peso específico dos tratores agrícolas fabricados no Brasil e seus efeitos sobre a seleção e uso. Ciência Rural, v.35, n.1, p.92-97, 2005. Available from: $<$ http://www.scielo.br/scielo.php?pid=S010384782005000100014\&script $=$ sci_arttext $>$. Accessed: Apr. 06, 2015. doi: 10.1590/S0103-84782005000100014. 